\title{
Class, Taste, and Literature: The Case of Ivar Lo-Johansson and Swedish Working- Class Literature
}

\author{
Magnus Nilsson, Malmö University
}

\begin{abstract}
This article discusses the tradition of Swedish working-class literature and the relationship between taste and class. First, I analyze the representation of this relationship in Swedish working-class writer Ivar Lo-Johansson's novel Kungsgatan [King Street] from 1935. Thereafter, I discuss the whole tradition of Swedish working-class literature-in which LoJohansson's novel occupies a central position. This tradition constitutes a challenge to received ideas about class and taste, mainly because its consecration as a central strand in Swedish literature and its dissemination to a mass audience in the working class make it problematic to uphold conventional distinctions between popular/working-class and high/bourgeois culture. Finally, I argue that the challenging of these distinctions is not only a key to a better understanding of Lo-Johansson's novel, but it also shows that Swedish working-class literature can serve as a catalyst for re-theorizations within working-class studies of the relationship between class and taste as something that is historically specific, rather than universal.
\end{abstract}

\section{Keywords}

Working-class literature, taste, class, Ivar Lo-Johansson, Sweden

\section{Introduction}

Ivar Lo-Johansson (1901-1990) is a central figure in the tradition of Swedish working-class literature (which will be described in more detail below). His parents were statare (contract farm workers that were hired on an annual basis and paid mainly in kind), and before becoming a professional author, he worked as, among other things, a stonemason and a peddler. In 1933, he had his definitive literary breakthrough with a more or less autobiographical novel about a young statare boy: Godnatt, jord (published in English in 1991 as Breaking Free). During the following decade, he published a number of novels, short stories, and reportages about the statare class, and many have argued that this contributed to the abolishment of the statare system through an agreement between the trade unions and the employers in 1945. Among LoJohansson's most important later works are a series of eight autobiographical novels published between 1951 and 1960, seven collections of short stories about human passions and vices from the period 1968-1972, and his memoirs in four volumes published between 1978 and 1985. Kungsgatan [King Street], which was first published in 1935, is one of Lo-Johansson's most well-known novels, and it has remained popular until today (as will be described in more detail later in the article).

The aim of this article is to show how Kungsgatan and the tradition of working-class literature to which it belongs can serve as an entry point for theorizing the relationship between taste and 
class. First, I will analyze how this relationship is represented in Lo-Johansson's novel. Thereafter, I will turn to Swedish working-class literature in general and discuss how it brings to the fore questions about taste and class. Above all, I will show that its consecration as a central strand in national literature and its dissemination to a mass audience in the working class constitutes a challenge to conventional distinctions between popular/working-class and high/bourgeois culture. However, the article makes an intervention not only in the study of Swedish working-class literature but also in the study of working-class literature in general, as well as in theoretical discourses about the relationship between class and taste within workingclass studies more broadly. The main claim in this article is that the relationship between class and taste should be viewed as historically specific rather than universal.

\section{Previous Research}

Swedish working-class literature is relatively well researched, and in recent years, it has received increased scholarly attention-especially within a Nordic network for the study of working-class literature, which has hitherto organized six conferences and published four edited collections (Agrell et al. 2016; Hamm, Nestås Mathisen \& Neple 2017; Jonsson et al. 2011; Jonsson et al. 2014).

Lo-Johansson has been the object of many academic studies, but although several of them focus on his novels from the 1930s, the scholarship on Kungsgatan is meagre. Ola Holmgren (1998) devotes a few pages to the novel in a monograph about Lo-Johansson's whole oeuvre, Maria Wahlström (2017) has examined its representation of prostitution, and Anna Williams (1999; 2002) has studied how it relates to processes of modernization. However, the novel's thematization of taste and class has not been analyzed explicitly. In fact, the topic of taste has generally not been prominent in research on Swedish working-class literature. Nevertheless, a few studies in recent years have addressed its representation in contemporary working-class novels (Arping 2011; Hamm 2016; Nilsson 2010).

In sociology, taste and class are central, but also contested, concepts. An overview of the main theoretical positions regarding their relationship that have been important within cultural studies can be found in an essay by Jon Cook. One of these positions Cook (2000 p. 102) associates with the cultural sociology of Pierre Bourdieu: it 'suggests a systematic co-relation between economic class and taste' and associates social elites with 'high culture' and the working class with 'popular culture.' Another position he associates — quite brilliantly—with the main character in the BBC sitcom Keeping up Appearances: Hyacinth Bucket (pronounced 'bouquet') (Cook 2000 p. 106). This position is based on the idea that taste 'finds its expression hierarchically' and that elites 'determine what is good taste, while 'those lower down imitate what has been decided by those above them' (Cook 2000 p. 107). However, those at the top of the social hierarchy can also imitate or appropriate styles emanating from the bottom (Cook 2000 p. 107). Yet another position that Cook (2000 p. 107) identifies is one from which taste is seen as a means for creating communities that are 'tangentially related to class, perhaps,' but not explained by 'the monolithic orders' of social classes.

In contemporary research about Swedish working-class literature, questions about class and taste have mainly been addressed with the point of departure in feminist sociologist Beverley Skeggs's theory about respectability (Arping 2011; Hamm 2016; Nilsson 2010). Drawing primarily on Bourdieu, but also on post-structuralist theorists like Foucault, Skeggs (1997) argues that upper- and middle-class people subject working-class people to symbolic violence 
by representing them as being unrespectable, for example, by associating their taste with unrespectability.

In recent decades, Bourdieu's theories about the relationship between taste and class have been subjected to much critique. One example, which is of special relevance for this article, can be found in Rune Sakslind and Ove Skarpenes' sociological analysis of the Norwegian middle class. Drawing on Michèle Lamont's comparative research — which has demonstrated that some of Bourdieu's theories seem to hold only in the French context where they were originally developed-Sakslind and Skarpenes (2014 p. 326) show that 'the culturally conditioned social interaction between classes in Norway follows a particular pattern that is quite different from continental models. Thus, they argue, 'the seeming universals of class theory' are not necessarily applicable everywhere (Sakslind \& Skarpenes 2014 p. 325). Consequently, they call for 'the study of class culture not as something universal, but as something particular, embedded in social formations' (Sakslind \& Skarpenes 2014 p. 331).

\section{Class and Taste in Kungsgatan}

Kungsgatan is a Bildungsroman. Its protagonist, Adrian, is a farmer's son who leaves the village where he has grown up and moves to Stockholm. He encounters many difficulties, the worst of which is that he is infected with gonorrhea, before managing to shed his rural identity and become a class-conscious urban proletarian. This story fits well into the main theme in LoJohansson's novels from the 1930s: the transformation of Sweden from a traditional rural society into a modern, urbanized nation in which the working class and the labor movement constitute the central social and political force (Nilsson 2003). However, one of the things that makes Kungsgatan stand out in Lo-Johansson's oeuvre is that its discussion of modernity and class often brings to the fore questions about taste.

Early in the novel, before moving to the city, Adrian attends a winter school for farmers. There, he articulates a conservative ideology, expressed in an essay in which he 'jämförde spinnrockens skönhet med en självbindande slåttermaskins och kasserade den sistnämnda' [compared the beauty of the spinning wheel to that of a self-binding mowing machine and discarded the latter] (Lo-Johansson 1935 p. 21). ${ }^{1}$ This conservatism is expressed as a taste judgement. Adrian prefers the old and agrarian over the modern and technical on what seems to be purely aesthetical grounds. That modern agricultural technology might be efficient, for example, seems not to matter; it is discarded because it is not as beautiful as a spinning wheel. Adrian's conservatism is also connected to his social position as the son of a farmer. For, in Kungsgatan, like in Johansson's novels from the 1930s in general, farmers are associated with the past and described in opposition to modernity, which is connected to urbanity and the working class (Nilsson 2003 p. 25-27). For example, the first section of Kungsgatan, which describes Adrian's childhood in the countryside, has the title 'På sextusen års grund' [On sixthousand-year-old ground] (Lo-Johansson 1935 p. 3).

During his stay at the school, Adrian begins to change. Above all, his encounter with the teachers makes him question not only his own taste but the taste of farmers in general:

Det minsta konstföremål på lärarnas väggar, även kopiorna, ett stycke mineral på deras bord, några blommor i en vas uppvägde allt böndernas mischmasch, som dessa smaklöst

\footnotetext{
${ }^{1}$ Kungsgatan has not been translated into English. All translated quotations in this article are my own, and do not capture the novel's aesthetic merits. The novel has, however, been translated into Danish, Norwegian, Icelandic, Finnish, German, Croatian, and Slovenian.
} 
samlade hos sig. ... Lärarna, dessa idealister, levde ett rikt liv på rätt knappa inkomster. I motsats till bönderna levde de ett djupare, klarare liv, också ett vackrare liv än böndernas så kallade friska, vilket mestadels saknade all lätthet och frihet, och därmed också saknade allt behag. (Lo-Johansson 1935 p. 23)

[The tiniest object of art on the teachers' walls, including the prints, a piece of mineral on their desks, some flowers in a vase, counterbalanced all the farmers' mishmash, that they collected because of their bad taste. ... The teachers, these idealists, led a rich life on rather meagre incomes. Unlike the farmers, they led a deeper, clearer life; it was also a more beautiful life than the so-called healthy life of the farmers, which mostly lacked all lightness and freedom and, thus, all pleasure.]

Being the son of a farmer, Adrian occupies a high position in his village. At the school, however, he feels inferior to the teachers. This inferiority is symbolic, rather than economic. The teachers are not richer than the farmers. But despite their meagre incomes, they lead richer lives. What makes their lives rich seems to be the fact that they have good taste.

This association of class difference with differences in taste continues in the description of Adrian's life in the city. It is expressed mainly through representations of so-called hötorgskonst, which The Swedish National Encyclopedia's Swedish-English dictionary translates as 'trashy (third-rate) art, kitsch.' The term comes from Hötorget, a square in central Stockholm where this kind of art used to be sold. It is located near Kungsgatan, the street which has given name to Lo-Johansson's novel. In the novel, this street is mainly associated with prostitution, and this association rubs off also on the paintings sold nearby. Thus, LoJohansson's proletarian novel seems to reproduce a rather aristocratic idea about art, namely that artistic value is the inversion of economic value, which is homologous to the idea that romantic love stands in absolute opposition to prostitution.

Hötorgskonst paintings are hand-painted, often made with templates, and mostly depict scenes from nature. In Kungsgatan, it is especially the latter that makes them appealing to workers in the city:

Det var i synnerhet om fredagskvällarna, som arbetarna intresserade sig för konst. De hade då fått avlöningen för veckan och de hade suttit på kaféerna och blivit en smula glada. Somliga ville bereda hustrun en överraskning när de kom hem sent med litet pengar. Då köpte de en tavla och tog den med. De kände först av allt efter om tavlan var riktigt torr. På motiven kunde de aldrig anmärka. De flesta motiven var från landet, och det var köparna med, men de hade nästan glömt bort, hur landet såg ut i verkligheten. De andra trodde blint, att landet var som på Hötorgsmålarens tavlor. (Lo-Johansson 1935 p. 31)

[It was especially on Friday nights that the workers took an interest in art. They had received the week's salary by then, and they had been sitting in cafés and become somewhat merry. Some of them wanted to surprise the wife when they came home late with little money. Thus, they bought a painting and brought it with them. They made sure first and foremost that the painting was really dry. They could never complain about the motifs. Most of the motifs were from the country, and so were the buyers, but they had almost forgotten what the country really looked like. The others believed blindly that the country looked like it did in the Hötorg-painter's paintings.] 
Thus, like Bourdieu and his followers, Lo-Johansson associates workers with popular art. His description of their focus on the paintings' content is also consistent with Bourdieu's claim that working-class taste is governed by an 'anti-Kantian aesthetic,' which 'gives priority to what works of art are about over how they are formed' (Cook 2000 p. 102).

However, Lo-Johansson also complicates the relationship between workers and popular art by emphasizing that the appeal of this art is a product of the workers' association with the countryside - that is, they have not yet liberated themselves from their former rural identities and become urban proletarians. Furthermore, he describes this kind of art as being ideological. In Anna William's (1999 p. 9) words, Lo-Johansson thematizes how 'consciousness is formed' and analyzes 'the role of art as both a creative and manipulative force in such processes.' The hötorgskonst paintings in Kungsgatan replace the 'real' countryside with a kitsch version of it, one that produces nostalgia, and thus hinder the development of a new, urban, proletarian identity among workers.

Moreover, the novel does not just represent urban workers as country folk in disguise. It also associates them with a desire to become bourgeois. This includes Adrian, at least initially:

Han ville ha ett arbete, där han fick gå ren om händerna och snyggt klädd. Det var vid en tid, då alla ville det. Det var en tid, då arbetarna ville se sina barn som borgare. Det var den tid, då kvinnan av alla klasser vart en liten dam. (Lo-Johansson 1935 p. 38)

[He wanted a job where he could walk around with clean hands and nice clothes. It was a time when everyone wanted that. It was a time when the workers wanted to see their kids become bourgeois. It was a time when women of all classes became little ladies.]

Even the most class-conscious urban proletarian in Kungsgatan-Adrian's mentor, the elderly construction worker Moderat-seems to have internalized bourgeois values, especially bourgeois taste. This is brought to the fore in a description of the room in Moderat's apartment that Adrian rents:

Det hade mörkbruna tapeter, kakelugn som sköt i tak i det höga rummet, toalett i farstun, en uråldrig chiffonjé, en plyschsoffa som kunde förvandlas till säng, kommod med paradhanduk, hemvävda trasmattor, underst korkmatta, en asparagus i en korg, fikus på ett trebensbord, knypplade dukar och på väggen en fotografi av Branting, uppflugen högst under taket. Alla prydnader var av gips, garn eller utgjordes av fotografier. Böcker fanns inte. Men på väggen, där soffan stod, hängde en hemsydd väggbonad på vilken lästes:

'Fågel söker fäste, människan söker bo.

Eget litet näste

ger den bästa ro' (Lo-Johansson 1935 53)

[It had dark-brown wallpaper, a tiled stove that rose toward the high ceiling, a toilet in the vestibule, an ancient desk, a plush sofa that could be turned into a bed, a washbasin with an embroidered towel, home-woven rag-carpets, linoleum underneath, an asparagus in a basket, an India-rubber tree on a three-legged table, pillow-lace, and on the wall a photograph of Branting, perched under the ceiling. There were no books. But 
on the wall, where the sofa was, there was a home-sewn tapestry on which one could read:
'A bird seeks its place
man seeks a home
A little nest of one's own
gives the best peace and quiet']

Branting was the leader of the Swedish labor movement. His picture is the only thing connecting the interior decoration in Moderat's home to the working class. Everything else indicates that the apartment is home to a family that mimics the bourgeoisie.

Toward the end of the novel, Adrian finally manages to break free of his old identity and become a class-conscious urban proletarian. At the same time, he also gains access to the world of high culture. The latter is exemplified by him visiting a theatre performance with his girlfriend, Tora, a class-conscious proletarian who has grown up in the city:

En kväll gick de på teatern, som spelade en av de sista gångerna för säsongen. Han upplevde med förödande styrka den stora konstens ödslighet, medan Tora tycktes ha svårare att förstå dessa ur ett gammaldags borgerligt hemlighetsmakeri uppståndna konflikter. Ett slag skämdes han också, medan han satt därinne. Det var vid tanken på föräldrarna, då han icke tyckt sig ha rätt att göra sig delaktig av kulturen, under det att föräldrarna arbetade utanför. (Lo-Johansson 1935 p. 357)

[One night they went to the theater, which gave one of the last performances of the season. He experienced, with devastating force, the desolation of great art, while Tora seemed to have greater difficulties understanding these conflicts emerging from oldfashioned bourgeois mystery-making. For a while, he was also ashamed while sitting there. It was when he thought of his parents, when he did not think that he had the right to participate in culture while his parents worked outside.]

This scene shows that Adrian has been able to overcome the alienation from the world of culture that he had previously experienced at the winter school in his role as the son of a farmer. This is connected to his change of social class - his breaking free from his identity as the son of a farmer-and is accentuated in the description of his insight that his parents, who are still farmers, have no access to the world of culture.

Much like Bourdieu, Lo-Johansson seems to insist on the co-relation between economic class and taste. In Kungsgatan, farmers, workers, and intellectuals display different tastes. However, there are aspects of the representation of class and taste in Lo-Johansson's novel that do not harmonize with the Bordieuan theoretical position. One aspect is that while Bourdieu and his followers see the distinction between the bourgeoisie and the working class as homologous with the one between highbrow and popular culture, Lo-Johansson paints a more complex picture. For example, he associates the workers' taste for kitsch art not with their proletarian class position but with their inability to liberate themselves from their previous rural identities. Thus, Adrian, who does manage to break free from his role as the son of a farmer and become a classconscious urban proletarian, develops a taste not for popular culture but for highbrow bourgeois culture. 
Lo-Johansson's representation of taste and class in Kungsgatan also has similarities with that theoretical position described by Cook that focuses on hierarchies and mimicking of taste. This is most evident in the description of Moderat's apartment. Perhaps, Adrian's and Tora's visit to the theater could also be seen as an example of mimicking bourgeois taste. However, the latter example indicates that Lo-Johansson's representation of taste hierarchies is rather complex. For, even if Adrian, toward the end of the novel, takes part in cultural activities explicitly described as being bourgeois and as being out of reach for both the urban proletariat (represented by Tora) and farmers (represented by his parents), he himself is described as having developed a proletarian class consciousness. Therefore, Adrian's visit to the theatre should perhaps be understood in analogy with the third position described by Cook: as an attempt to become a member of a community that is only 'tangentially' (or perhaps not at all) related to social class.

\section{Swedish Working-Class Literature and Taste}

Kungsgatan brings to the fore questions about taste and class not only on the level of content but also through its very status as a work of literature belonging to the tradition of Swedish working-class literature.

According to the standard narrative about its history, working-class literature first emerged in Sweden during the second half of the nineteenth century within the labor movement (Furuland \& Svedjedal 2006 p. 4-5; Nilsson 2017 p. 96). The literature produced and read there differed from bourgeois literature in several ways. For instance, politics was more important than aesthetics (Mral 1985 p. 15), and working-class literature had a collective rather than an individual(istic) character (Nilsson 2006, p. 36-37). In addition, working-class writers mainly used short formats, such as poems and songs (Furuland \& Svedjedal p. 55-56). Thus, early Swedish working-class literature could very well be - and has indeed been-conceptualized as an expression of a class-specific taste; this, in turn, can be connected to material conditions specific to the working class, such as the lack of economic means, leisure time, and education necessary for reading novels (Nilsson 2006 p. 38).

However, literary life within the labor movement was in no way totally autonomous from other parts of society. For example, many working-class writers borrowed forms and motifs from bourgeois and religious literature (Nilsson 2006 p. 37). Accordingly, it cannot be viewed as expressing only proletarian taste. The fact that it existed solely within the labor movement also means that working-class literature was not a concern for the working class in its entirety, only for those workers who were class conscious and politically organized. Hence, it cannot be seen as an expression of all workers' taste. Furthermore, early Swedish working-class literature aimed at creating class consciousness (Mral 1985 p. 15). Therefore, it should perhaps be viewed not as expressing but as producing taste (for example, in the form of taste for literature expressing socialist ideals). Since the labor movement aimed at transforming the working class by instilling it with socialist ideas, this taste should perhaps not be associated with the (existing) working class but with a (not yet fully existing) community centered on the labor movement's socialist ideology.

Consequently, the history of early Swedish working-class literature seems to challenge the idea that literary taste can be directly connected to social classes. Its later history also calls into question some ideas about taste hierarchies and their relationship to class hierarchies. 
Early in the twentieth century, a number of working-class writers - among others Maria Sandel, Dan Andersson, Martin Koch, and Gustav Hedenvind-Eriksson-became successful outside the labor movement (Furuland \& Svedjedal 2006 p. 78-79). Some ten years later, another group of working-class writers that included Ragnar Jändel, Ivan Oljelund, and Harry Blomberg also managed to establish themselves in the site of national literature (Uhlin 1950 p. 210-211). In the 1930s, working-class literature had its definitive breakthrough in Swedish literature with the emergence of a generation of working-class writers to which belonged Harry Martinson, Josef Kjellgren, Vilhelm Moberg, Moa Martinson, Jan Fridegård, and Ivar Lo-Johansson (Furuland \& Svedjedal 2006 p. 216-219). After World War II, working-class literature was consecrated as a central strand in Swedish national literature (Nilsson 2014 p. 21-22). Perhaps the best symbol of this position is that in 1974 the Nobel Prize in literature was awarded to Harry Martinson and Eyvind Johnson as representatives for 'the many proletarian writers or working-class poets' in Swedish literature (Gierow 2018).

Some commentators have argued that the breakthrough for and consecration of working-class literature in Swedish national literature was a result of working-class writers abandoning the proletarian aesthetics that had been developed within the labor movement and instead catering to bourgeois literary tastes. For instance, Arne Melberg (1973 p. 85) argued that working-class literature was 'absorbed' by bourgeois literary institutions, whereas Birgitta Holm (1975 p. 247) claimed the confrontation between working-class writers and the bourgeois institution of literature resulted in the former 'succumbing.' In light of these ideas, the breakthrough for and consecration of working-class literature in Swedish national literature appears to be examples of the bourgeoisie (mis)appropriating working-class literature while keeping the existing hierarchies of taste intact. However, in the following, I will argue that it represents a reconfiguration of these hierarchies.

One indication that the consecration of Swedish working-class literature has indeed reconfigured the dominant taste hierarchies is that it was opposed by many bourgeois critics, who in the 1920s and 1930s did their best to condemn this literature. The most notorious of them was Sven Stolpe, who from 1926 launched a series of attacks on the emerging generation of working-class writers (Nordmark 1978 p. 17). In an article published in 1928, for example, he argued that the rise of working-class literature represented an unfortunate tendency toward democratic levelling within the realm of literature (Stolpe 1928).

Stolpe's rejection of working-class literature has the form of a taste judgement. On the one hand, he admitted that the worker is a legitimate motif in literature. No 'sane person,' he argued, 'any longer subscribes to the classical doctrine that literature should exclusively depict kings, princes, and their likes,' and he claimed that writers' interest in 'modern social life, including its everyday or repulsive forms' has made the Swedish novel 'richer' (Stolpe 1928). On the other hand, he argued that when it comes to literary form, working-class literature has no merits: 'Actually, all is said if one claims that working-class writing is naturalistic: a more antiquated literary style, a theory that is more at odds with the innermost trends of our time is hard to find' (Stolpe 1928). In other words, those who appreciate working-class literature are out of touch with contemporary taste.

Stolpe's critique of working-class literature for being aesthetically backward is far from unique. As has been demonstrated by Valentine Cunningham (1997 p. 5), among others, radical literature from the 1930s has often been associated with older literary styles - thereby possible to condemn as a 'historical blip or bypass on which writing got snagged and slowed down in the long march of the twentieth century from modernism at the beginning to modernism at the 
end.' In response to such accusations, much scholarly energy has been invested in attempts to establish links between this literature and the dominant, or even avant-garde, aesthetic discourses of its time.

In Sweden, this has mainly taken the form of emphasizing the links between 1930s workingclass literature and modernism (Nilsson 2003; Witt-Brattström 1988). This research is not without merits. Many Swedish working-class writers were indeed influenced by modernist aesthetics, and this needs to be acknowledged. However, even if this means that they were in touch with the most advanced aesthetic ideas of their time, it does not mean that they did not challenge the dominant literary taste. The (counter) attacks by Stolpe and other leading bourgeois critics is evidence of this. Further, since modernism was not considered an important strand in Swedish literature until after World War II, the modernistic features of 1930s workingclass literature were also condemned as violations of good taste. These condemnations, however, did not only come from bourgeois critics; they also came from critics affiliated with the labor movement. The most well-known of these is the Marxist critic and poet Ture Nerman, who accused the modernists among working-class writers of aestheticism and escapism and who has gone down in history as Swedish modernism's enemy number one (Nilsson 2003 p. 245-253).

It was not only its modernist tendencies that made 1930s Swedish working-class literature a target for critique from the labor movement. As has already been mentioned, Lo-Johansson had his definite literary breakthrough in 1933 with the novel Godnatt jord [Breaking free]. Together with two other novels published the same year-Moa Martinson's Kvinnor och äppelträd [Women and Apple Trees] and Jan Fridegård's En natt $i$ juli [A Night in July] —it also marked the breakthrough of the most important genre in 1930s Swedish working-class literature, namely the more or less autobiographical proletarian Bildungsroman. Some critics affiliated with the labor movement received Lo-Johansson's novel positively. One of them was Alfred Kämpe, who even compared its author with August Strindberg (Furuland 1976 p. 73). Nevertheless, some critics within the labor movement condemned the novel for being too pessimistic and for maligning working-class people (Furuland 1976 p. 73-75). A similar criticism was also put forward by some bourgeois critics, who objected to Lo-Johansson's alleged naturalism, thereby reproducing the critique of working-class literature formulated by Stolpe a few years earlier (Furuland 1976 p. 76-77).

In the 1930s, Swedish working-class literature challenged the dominant literary taste. The opposition facing working-class writers from bourgeois critics might imply a clash between classes. However, the fact that some critics affiliated with the labor movement also condemned working-class literature indicates that things are in fact more complicated.

Another complicating fact is that the breakthrough for Swedish working-class literature in the 1930s was mainly a breakthrough in intellectual circles, to which most workers did not have access. For example, the first edition of Lo-Johansson's Kungsgatan was printed in 2,200 copies, with three additional printings of 1,000 extra copies over the next five months (Furuland \& Oldberg 1961 p. 14). These relatively low numbers - combined with the fact that it was published not by any working-class press but by Sweden's most prestigious publishing house, Bonniers - indicate that the novel did not reach any substantial audience within the Swedish working class, which at the time consisted of around one and a half million people (Therborn 1981 p. 47). Thus, 1930s Swedish working-class literature seems to have much weaker connections to the working-class than the older working-class literature that was produced, circulated, and read within the labor movement. 
However, in the 1940s and 1950s, many working-class writers did in fact reach mass readerships among workers, mainly through cheap editions of their works from the 1930s that were targeting working-class audiences (Nilsson 2006 p. 75-77). For example, in 1943, Bonniers published a moderately priced two-volume edition of Kungsgatan. At first, 45,000 copies were printed, followed by another 20,000 (Furuland \& Oldberg 1961 p. 14). In 1950, a more expensive bound edition, again in two volumes, was printed in 40,000 copies. In addition, Kungsgatan was serialized in two labor-movement newspapers in 1944 and in 1947-48 (Furuland \& Oldberg 1961 p. 14). It was also filmed in 1943 (Furuland \& Oldberg 1961 p. 124125).

Besides eventually becoming popular among reading workers, the working-class literature of the 1930s has also, retroactively, been embraced by the labor movement. For example, the Swedish Trade Union Confederation has instituted a literary prize in Lo-Johansson's name, which is given out every year to an 'important working-class writer' (Ivar Lo-priset 2018).

Working-class literature has remained an important strand in Swedish literature until today in terms of both its status as high literature and its popularity. This is most evident in LoJohansson's case. In the definitive work about Swedish literary history, Den svenska litteraturen [Swedish literature] — whose volume about the period 1920-1950 has the subtitle 'Modernister och arbetardiktare' [modernists and working-class writers]-more than seven pages are devoted to Lo-Johansson (whose picture also appears on the back cover) (Lönnroth $\&$ Delbland 1993). He has also remained one of the most-read Swedish authors. For example, Kungsgatan has continued to appear in new editions, including easy-to-read versions, audio books, and electronic books. In 2015, it was selected book-of-the-year by the project 'Stockholm läser' [Stockholm reads]. The project activities included reading circles, lectures, film screenings, and literary walks (Stockholm läser 2018). Two new editions of Kungsgatan were published for the project: one easy-to-read-version and one full-length version with a foreword by contemporary working-class writer Susanna Alakoski. During the project, Kungsgatan became the most borrowed book at Stockholm's public library (Nummer ett 2018).

The fact that Swedish working-class literature is a central strand in national literature, at the same time as it is embraced by the labor movement and popular among both workers (at least historically) and reading people in general, challenges some ideas about the relationship between class and taste. Above all, it makes it difficult to argue that what workers like is popular literature, while the bourgeoisie enjoys high literature. It also calls into question the idea that hierarchies of taste are analogous with class hierarchies. After all, Sweden is a capitalist society, in which the bourgeoisie is the dominant class. At the same time, the dominant literary taste does not exclude working-class literature.

\section{Conclusion}

Swedish working-class literature challenges common ideas about the relationship between class and taste, which shows that such ideas are marked by the contexts in which they emerge. For example, Pierre Bourdieu's cultural sociology — which remains one of the central theories about this relationship despite the recent criticism - has been developed in a context (France) where working-class literature has been neither popular among workers nor considered high literature. The same can be said about those theories which emphasize the rigidity of hierarchies of taste and describe negotiations between classes in terms of mimicking and appropriation. After all, Hyacinth Bucket is indeed a very British lady. 
Attention to historical specificities can help clarify some puzzling aspects of the representation of class and taste in Lo-Johansson's Kungsgatan. The novel's protagonist, Adrian, struggles to break free from his earlier identity and become a class-conscious proletarian. However, at the same time as he completes this transformation, he also discovers high art. Thus, from the perspective of Bourdieu's sociology of culture, it would seem as if he is simultaneously gaining access to and becoming alienated from the working class. From another theoretical position, he could be interpreted as someone who, as he becomes a proletarian, mimics the taste of those above him or inscribes himself in a community that has no direct relation to class. However, if one considers that Lo-Johansson belonged to a generation of working-class writers whose works were about to become an important strand in modern Swedish literature, it is far from impossible to imagine that he might not have viewed the realm of high literature as a bourgeois domain or as a realm outside of class society. Instead, he may have viewed it as domain that would not remain exclusively bourgeois much longer. Then, Adrian's going to the theater is not necessarily a mimicking of bourgeois taste or a transience of class-based tastes-it could just as well be him entering a sphere from which he has hitherto been excluded but which he now, after having become a class-conscious worker, intends to conquer.

This shows that Swedish working-class literature provides productive avenues to re-theorize conventional scholarly understandings of the relationship between class and taste. This is no less true regarding the common distinction between popular/working class and high/bourgeois culture. Accordingly, working-class studies could benefit from more comparative studies that make visible the complexity of class and its relationship to phenomena such as taste, as well as the influence of historical contexts.

\section{Author Bio}

Magnus Nilsson is professor of comparative literature at Malmö University, Sweden. He is the author of many studies of working-class literature, including Literature and Class: AestheticalPolitical Strategies in Modern Swedish Working-Class Literature, published by the Humboldt University in Berlin in 2014. Together with John Lennon, he is the editor of Working-Class Literature(s): Historical and International Perspectives, published by Stockholm University Press in 2017.

\section{Bibliography}

Agrell, B., Arping, Å., Ekholm, C. and Gustafson, M. (eds), 2016, 'Inte kan jag berätta allas Historia?': föreställningar om nordisk arbetarlitteratur, Göteborgs universitet/ Institutionen för litteratur, idéhistoria och religion, Göteborg.

Arping, Å. 2011, 'Att göra skillnad: Klass, kön och etnicitet i några av det nya seklets uppväxtskildringar', in B. Jonsson, M. Nilsson, B. Sjöberg \& J. Vulovic (eds.), Från Nexø till Alakoski: Aspekter på nordisk arbetarlitteratur, Absalon, Lund, pp. 189-198.

Cook, J. 2000, 'Culture, class and taste', in S.R. Munt (ed.), Cultural studies and the working class: subject to change, Cassell, London \& New York, pp. 97-112.

Cunningham, V. 1997, 'The age of anxiety and influence; or, tradition and the thirties talents', in K. Williams \& S. Matthews (eds.), Rewriting the thirties: modernism and after, Longman, London \& New York, pp. 5-22. 
Furuland, L. 1976, Statarnas ombudsman i dikten: En bok om Ivar Lo-Johansson, Stockholm: LT/Svenska lantarbetarförbundet, Stockholm.

Furuland, L. \& Oldberg, R. 1961, Ivar Lo-Johansson i trycksvärtans ljus: En bibliografi 23 februari 1961, Bonniers, Stockholm.

Furuland, L. \& Svedjedal, S. 2006, Svensk arbetarlitteratur, Atlas, Stockholm.

Gierow, K. R. 2018, viewed 18 November 2018, <https://www.nobelprize.org/prizes/literature/1974/ceremony-speech/>.

Hamm, C. 2016, 'Den 'vinröda yllefilten' og andre gjenstander i Susanna Alakoskis Svinalängorna (2006): Arbeiderlitteraturens svar på tingteori', in E. Igland Diesen, O. Karlsen \& E. Stengrundet (eds.), Stempelslag: Lesninger i nordisk politisk litteratur, Novus folag, Olso, pp. 189-213.

Hamm, C., Nestås Mathisen, I. \& Neple, A. (eds.), 2017, Hva er arbeiderlitteratur?: begrepsbruk, kartlegging og forskningstradisjon, Alvheim \& Eide, Bergen.

Holm, B. 1975, 'Efterkrigstidens litterära institution: Borgerlig jagidentitet och borgerlig emancipatorik i En privatmans vedermödor', in A. Melberg (ed), Den litterära institutionen: Studier $i$ den borgerliga litteraturens historia, Rabén \& Sjögren, Stockholm, pp. 240-272.

Holmgren, O. 1998, Ivar Lo-Johansson: Frihetens väg, Natur \& Kultur, Stockholm.

Ivar Lo-Priset 2018, viewed 19 November 2018, 〈http://www.ivarlopriset.se/om-priset/>.

Jonsson, B., Nilsson, M. Sjöberg, B. \& Vulovic, J. (eds.), 2014, Från bruket till yarden: Nordiska perspektiv på arbetarlitteratur: Lunds universitet: Språk- och litteraturcentrum: Litteraturvetenskap, Lund.

Jonsson, B., Nilsson, M. Sjöberg, B. \& Vulovic, J. (eds,), 2011, Från Nexø till Alakoski: Aspekter på nordisk arbetarlitteratur. Lunds universitet/Språk- och litteraturcentrum/ Litteraturvetenskap, Lund.

Lo-Johansson, I. 1933, Godnatt, jord, Bonniers, Stockholm.

---. 1935, Kungsgatan, Bonniers, Stockholm.

---. 1990, Breaking Free, trans. R. Wright, University of Nebraska Press, Lincoln.

Lönnroth, L. \& Delblanc, S. 1993, Den svenska litteraturen V: Modernister och arbetardiktare 1920-1950, Bonnier Alba, Stockholm.

Melberg, A. 1973, På väg från realismen: En studie i Lars Ahlins författarskap, dess sociala och litterära förutsättningar, Gidlunds, Stockholm.

Mral, B. 1985, Frühe Schwedische Arbeiterdichtung: Poetische Beiträge in Sozialdeokratischen Zeitungen 1882-1990, Uppsala Universitet, Uppsala.

Nilsson, M. 2006, Arbetarlitteratur, Studentlitteratur, Lund.

---. 2010, Den föreställda mångkulturen: Klass och etnicitet i svensk samtidsprosa, Gidlunds, Hedemora.

---. 2014, Literature and class: aesthetical political strategies in modern Swedish working-class literature, Nord-Europa Institut der Humboldt-Universität, Berlin.

---. 2017, 'The making of Swedish working-class literature', in J. Lennon \& M. Nilsson (eds.), Working-class literature(s): historical and international perspectives, Stockholm University Press, Stockhollm, pp. 95-127.

---. 2003, Den moderne Ivar Lo-Johansson: Modernisering, modernitet och modernism $i$ statarromanerna, Gidlunds, Hedemora.

Nordmark, D. 1978, Samhället på scenen: En studie i Rudolf Värnlunds drama Den heliga familjen - Dess litterära och sociala förutsättningar, Umeå universitet, Umeå.

Nummer Ett. 2018, viewed 18 November 2018, <http://bloggar.biblioteket.se/stockholmlaser/nummer-ett> 
Sakslind, R. \& Skarpenes, O. 2014, 'Morality and the middle class: the European pattern and the Norwegian singularity', Journal of Social History, vol. 48, no. 2, pp. 313-340.

Skeggs, B. 1997, Formations of class and gender: becoming respectable, Sage, London.

Stockholm Läser. 2018, viewed 18 November 2018, <http://bloggar.biblioteket.se/stockholmlaser/>.

Stolpe, S. 1928, 'Dikten Och Demokratin', Nya Dagligt Allehanda, 25 June.

Therborn, G. 1981, Klasstrukturen i Sverige 1930-1980: arbete, kapital stat och partiarkat, Zenit, Lund.

Uhlin, E. 1950, Dan Andersson före Svarta ballader: Liv och diktning fram till 1916, Tiden, Stockholm.

Wahlström, M. 2017, “Ett långt golv att gå sig trött på’: Om prostitution och de prostituerade i Ivar Lo-Johanssons Kungsgatan', Tidskrift För Litteraturvetenskap, vol. 47, no. 1, pp. 34-44.

Williams, A. 1999 'Kungsgatans Moderna Tider', Samlaren, vol. 120, pp. 5-25.

Williams, A. 2002, Tillträde till den nya tiden: Fem berättelser om när Sverige blev modernt,: Brutus Östlings bokförlag Symposion, Eslöv.

Witt-Brattström, E. 1988, Moa Martinson: Skrift och drift i trettiotalet, Norstedts, Stockholm. 